\title{
STABILITY INDICATING RP-HPLC METHOD FOR THE ESTIMATION OF DIETHYLCARBAMAZINE CITRATE, GUAIPHENESIN AND CHLORPHENIRAMINE MALEATE
}

\author{
PODILI BHAVANI, SEELAM MOHAN, KAMMELA PRASADA RAO*
}

Department of Chemistry, Bapatla Engineering College, Bapatla, Guntur (DT), AP., India

Email: prasad17467@gmail.com

Received: 22 Aug 2017, Revised and Accepted: 18 Dec 2017

\begin{abstract}
Objective: The present work describes the development and subsequent validation of a simple, precise and stability-indicating reversed-phase high-performance liquid chromatography (RP-HPLC) method for the simultaneous estimation of diethylcarbamazine citrate, guaiphenesin and chlorpheniramine maleate in tablet dosage forms.

Methods: A simple, accurate, precise and robust RP-HPLC method was developed and validated for the estimation of diethylcarbamazine citrate, guaiphenesin and chlorpheniramine maleate. The chromatographic separation of all the three active components was achieved by using luna phenyl-hexyl column ( $250 \mathrm{mmx} 4.6 \mathrm{~mm}, \mathrm{dp}=5 \mu \mathrm{m})$ with a mobile phase consisting of isocratic method with $0.1 \%$ triethylamine as buffer along with orthophosphoric acid adjusted to $\mathrm{P}^{\mathrm{H}} 2.5$ : acetonitrile $(50: 50 \mathrm{v} / \mathrm{v})$ at a flow rate $1.0 \mathrm{ml} / \mathrm{min}$ and ultraviolet detection at $210 \mathrm{~nm}$.

Results: The retention time of chlorpheniramine maleate, guaiphenesin and diethylcarbamazine citrate were $2.86,4.89$ and 7.76 min respectively. Validation of the proposed method was carried out according to an international conference on harmonization (ICH) guidelines. The established method was linear in the range of $1-15,0.6-9,0.02-0.3 \mu \mathrm{g} / \mathrm{ml}$ and correlation coefficient was $0.999,0.9991$, and 0.993 for diethylcarbamazine citrate, guaiphenesin and chlorpheniramine maleate respectively.
\end{abstract}

Conclusion: The proposed method can be used for the quantitative analysis of diethylcarbamazine citrate, guaiphenesin and chlorpheniramine maleate.

Keywords: Diethylcarbamazine citrate, Guaiphenesin and Chlorpheniramine maleate

(C) 2018 The Authors. Published by Innovare Academic Sciences Pvt Ltd. This is an open-access article under the CC BY license (http://creativecommons.org/licenses/by/4.0/) DOI: http://dx.doi.org/10.22159/ijap.2018v10i1.22180

\section{INTRODUCTION}

Diethylcarbamazine citrate, chemically $N, \quad N$-diethyl-4-methyl piperazine-1-carboxamide dihydrogen citrate [1] is one of the essential medicines needed in a basic health system, suggested by world health organisation (WHO) [2]. It is used in the treatment of filariasis including lymphatic filariasis, tropical pulmonary eosinophilia and loiasis.<smiles>CN(C)CCC(c1ccccc1)c1ccccn1</smiles>

Fig. 1: Chemical structure of diethylcarbamazine citrate

Guaiphenesin, chemically (S, S)-2-methlylamino-1-phenylpropan-1ol hydrochloride [3, 4], mainly used as a cough remedy. It has been given to patients which have altered nasal mucociliary clearance associated with HIV. It is used to remove phlegm from the airways in acute respiratory tract infections.<smiles>COc1ccccc1OCC(O)CO</smiles>

Fig. 2: Chemical structure of guaiphenesin

As chlorpheniramine maleate, chemically (RS)-3-(4-chlorophenyl)3-(pyrid-2-yl) propyl dimethylamine hydrogen maleate [5], has the relatively less sedative effect it is most commonly used as an antihistamine in small animal veterinary practices.<smiles>CCN(CC)C(=O)N1CCN(C)CC1</smiles>

Fig. 3: Chemical structure of chlorpheniramine maleate

The literature survey revealed that several analytical methods have been reported for the estimation of diethylcarbamazine citrate [6], guaiphenesin [7] and chlorpheniramine maleate $[8,9]$ individually or in combination with other drugs by UV-visible spectrophotometry, nuclear magnetic resonance spectroscopy, highperformance liquid chromatography methods [10-13]. No method has been developed for the simultaneous determination of diethylcarbamazine citrate, guaiphenesin, chlorpheniramine maleate both in bulk and pharmaceutical dosage forms.

On the meticulous observance of the potential applications of these three active drugs, we aimed to develop and validate a new, rapid and sensitive RP-HPLC method for simultaneous estimation of diethylcarbamazine citrate, guaiphenesin, and chlorpheniramine maleate. Degradation studies (stress studies) were carried out to establish the stability characteristics of the three ingredients under heat, acid, base, peroxide, light and reductive stress conditions as recommended in the ICH guidelines Q1A (R2).

\section{MATERIALS AND METHODS}

\section{Instrumentation}

The analysis was performed on waters alliance-2695 chromatographic system, equipped with a quaternary pump and PDA 
detector-2996. Chromatographic software empower-2.0 was used for data collection and processing.

\section{Chemicals and reagents}

Acetonitrile (HPLC grade), triethylamine (HPLC grade), orthophophoric acid (HPLC grade), water (HPLC grade) were purchased from Merk (India) Ltd, Worli, Mumbai, India. All active pharmaceutical ingredients (APIs) of diethylcarbamazine citrate, guaiphenesin and chlorpheniramine maleate as reference standards were procured from Supriya life Sciences, Goregaon (E), Mumbai, India (99.7-99.9 \% purity).

\section{Chromatographic conditions}

Chromatographic analysis was done using isocratic elution and acetonitrile: $0.1 \%$ triethylamine $\mathrm{PH}^{\mathrm{H}}$ adjusted to 2.5 with OPA (50:50 by volume) as a mobile phase and was filtered through $0.45 \mu$ membrane filter paper. The flow rate of the mobile phase was monitored at $1 \mathrm{ml} / \mathrm{min}$ and eluents were detected at $210 \mathrm{~nm}$. Operating pressure 3000 psi was maintained at room temperature by injecting the volume $10 \mu \mathrm{l}$ with a run time $10 \mathrm{~min}$.

\section{Selection of wavelength}

By using photodiode spectrophotometer the absorption spectra of the solution of the three drugs in acetonitrile were scanned in the UV region $200-400 \mathrm{~nm}$ against acetonitrile as blank and spectra are shown in fig. From the fig. the spectra of the diethylcarbamazine citrate, guaiphenesin and chlorpheniramine maleate shows different $\lambda \max$ viz. $254.5,255.6$ and $369.4 \mathrm{~nm}$ respectively. By considering the chromatographic parameter, sensitivity and selectivity of a method for three drugs $210 \mathrm{~nm}$ was selected as the detection wavelength for HPLC chromatographic method.

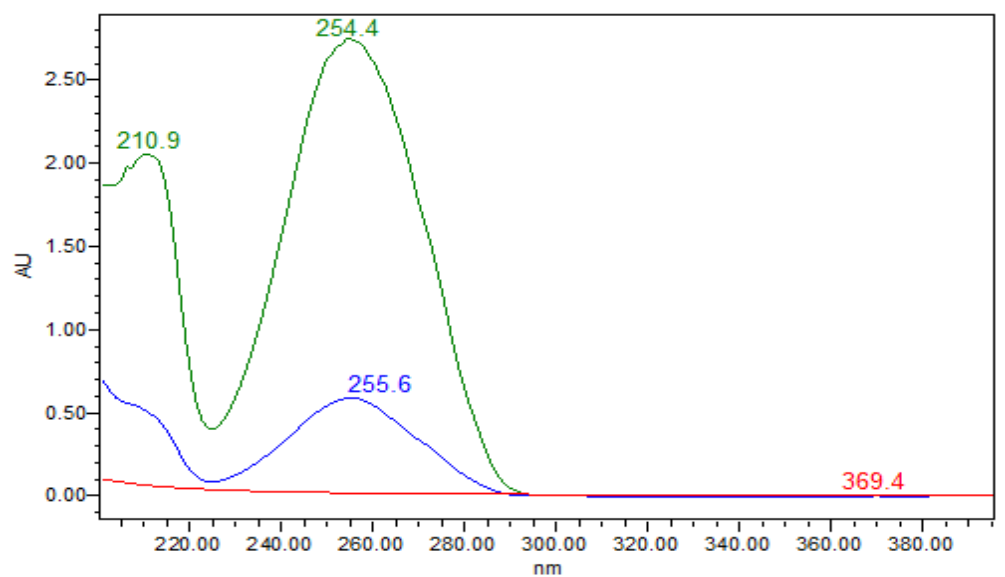

Fig. 4: PDA spectrum for diethylcarbamazine citrate, guaiphenesin and chlorpheniramine maleate

\section{Preparation of standard solution}

$100 \mathrm{mg}$ of diethylcarbamazine citrate, $60 \mathrm{mg}$ of guaiphenesin, $2 \mathrm{mg}$ of Chlorpheniramine maleate (working standard) were weighed accurately and transferred into a $100 \mathrm{ml}$ volumetric flask. $70 \mathrm{ml}$ of mobile phase was added to the above flask and then sonicated about $20 \mathrm{~min}$ for uniform mixing and then diluted $1 \mathrm{ml}$ of the above solution to $10 \mathrm{ml}$ with the mobile phase and again $1 \mathrm{ml}$ of the solution was diluted to $10 \mathrm{ml}$ with same mobile phase.

\section{Preparation of sample solution}

10 tablets were weighed and pulverised to powder form, from which one equivalent weight $(437.5 \mathrm{mg}$ ) was taken into $100 \mathrm{ml}$ volumetric flask.70 ml of mobile phase was added to the above flask and then sonicated about $20 \mathrm{~min}$ for uniform mixing. $1 \mathrm{ml}$ of the above solution was diluted to $100 \mathrm{ml}$ with the mobile phase and filtered through $0.45 \mu$ nylon syringe filter.

\section{Validation}

The optimized chromatographic separation was aimed to obtain a resolution above 1.5 between all components, tailing factor is less than 2.0 and plate count will be more than 2000 with respect to the stationary, mobile phase compositions, flow rate, sample volume, detection wavelength and temperature.

\section{Validation procedure}

In the present method validation was done with the aspect of system suitability, specificity, accuracy, precision, linearity, robustness, limit of detection (LOD), limit of quantitation (LOQ), forced degradation and stability according to the ICH guidelines [14-18].

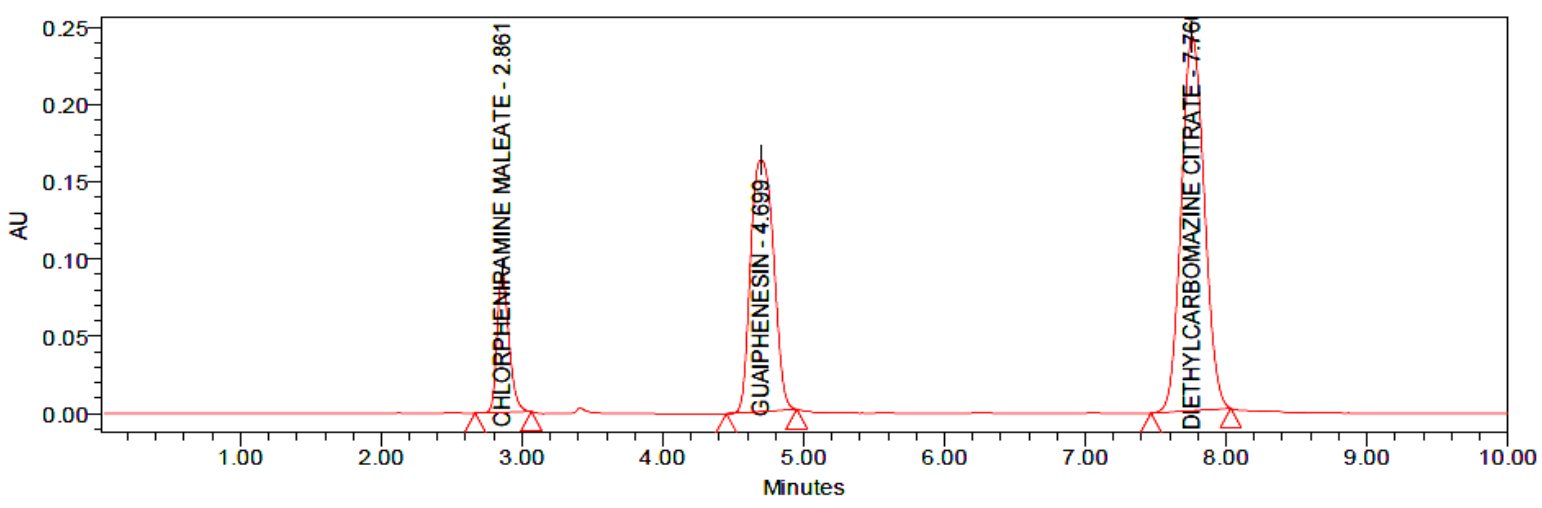

Fig. 5: Typical chromatogram for diethylcarbamazine citrate, guaiphenesin and chlorpheniramine maleate 


\section{System suitability}

As per the test method the standard and check standard solutions were prepared and injected into HPLC system $[10,11]$, from which the evaluated system suitability parameters are found to be within the limits.

\section{Specificity}

The analyte was assessed unequivocally to know the components impurity which may be expected to be present with the help of specificity. As per test method blank was prepared and injected. No blank peak was eluted in the retention time of analyte peak. Placebo solutions were prepared in duplicate and injected as per test method. It was found that no placebo peaks were interfered at the retention time of the main peak.

\section{Accuracy}

Three different concentrations such as lower quantitation limit, medium quantitation limit, and higher quantitation limit were used to evaluate the accuracy of the RP-HPLC method. The amount of the drugs present, percentage recovery and RSD were calculated by giving a minimum of three injections from each concentration.

\section{Precision}

The precision of the test method was evaluated by considering six different concentrations. The amount of the drugs present, percentage recovery and RSD were calculated by giving a minimum of six preparations.

\section{Linearity and range}

Six series of standard solutions were selected for assessing linearity range. By using peak area versus concentration of the standard solution calibration curve was plotted and the regression equations were also calculated. The slope, intercept and the correlation coefficient was calculated by least squares method.

\section{LOD and LOQ}

By using optimized chromatographic conditions in accordance with $3.3 \mathrm{~s} / \mathrm{n}$ and $10 \mathrm{~s} / \mathrm{n}$ criteria, where $\mathrm{s} / \mathrm{n}$ indicates signal-to-noise ratio, the LOD and LOQ were determined by injecting progressively lower concentrations of the standard solutions into the HPLC column.

\section{Forced degradation}

In chromatogram of forced degradation there should be no interference between peaks and were well separated from each other with the resolution at least 1.0 and the peak purity of the principal peaks should pass. Forced degradation studies were performed by different types of stress conditions to obtain the degradation of about $20 \%$.

\section{Robustness}

Small changes such as $\pm 5 \%$ in the ratio of acetonitrile in the mobile phase, $\pm 0.2 \mathrm{ml} / \mathrm{min}$ in the flow rate and $\pm 5 \mathrm{~nm}$ in the wavelength were made to demonstrate the robustness method. The separation factor, retention time and peak asymmetry were calculated.

\section{Stability}

Standard and the sample solutions were subjected to $24 \mathrm{~h}$ stability studies. The stability of these solutions was studied and observed for changes in the area and retention time of the peaks which were then compared with the pattern of the chromatogram of the freshly prepared solution.

\section{RESULTS AND DISCUSSION}

\section{Method validation}

In this method system suitability, linearity, precision, accuracy, robustness, LOD (Limit detection), LOQ (Limit of quantification), forced degradation and the stability are validated for the selected diethylcarbamazine citrate, guaiphenesin and chlorpheniramine maleate drugs.

\section{System suitability}

$10 \mu \mathrm{l}$ of working standard solution $(10 \mu \mathrm{g} / \mathrm{ml}$ of diethylcarbamazine citrate, $6 \mu \mathrm{g} / \mathrm{ml}$ of guaiphenesin and $0.2 \mu \mathrm{g} / \mathrm{ml}$ of chlorpheniramine maleate) was prepared and injected into the system. It was determined by making six replicate injections and all the parameters were found to be within the limits. The results are given table 1.

Table 1: System suitability parameters for diethylcarbamazine citrate, guaiphenesin and chlorpheniramine maleate

\begin{tabular}{llll}
\hline System suitability parameter & Diethylcarbamazine citrate & Guaiphenesin & Chlorpheniramine maleate \\
\hline Retention time (min) & 7.850 & 4.715 & 2.900 \\
Theoretical plate number (N) & 10909 & 4416 & 5810 \\
Tailing factor (T) & 1.062 & 1.145 & 1.271 \\
Resolution (R) & 10.693 & 8.386 & - \\
\hline
\end{tabular}

\section{Linearity}

The linearity of the proposed method was constructed by considering concentration on the $\mathrm{x}$-axis and peak area on the $\mathrm{y}$-axis. It was established by least squares linear regression analysis of the calibration curve. The calibration curve was linear in the range of 1-
$15, \quad 0.6-9, \quad 0.02-0.3 \mu \mathrm{g} / \mathrm{ml}$ for diethylcarbamazine citrate guaiphenesin and chlorpheniramine maleate respectively. The regression equation for calibration curve was $Y=561967 \mathrm{x}+13655$ $\left(\mathrm{r}^{2}=0.999\right)$ for diethylcarbamazine citrate, $\mathrm{Y}=474141 \mathrm{x}+21692$ $\left(r^{2}=0.999\right)$ for guaiphenesin and $Y=951864 x+4648\left(r^{2}=0.999\right)$ for chlorpheniramine maleate. The results are given in table 2 .

Table 2: Linearity data for diethylcarbamazine citrate, guaiphenesin and chlorpheniramine maleate

\begin{tabular}{|c|c|c|c|c|c|}
\hline \multicolumn{2}{|c|}{ Diethylcarbamazine citrate } & \multicolumn{2}{|c|}{ Guaiphenesin } & \multicolumn{2}{|c|}{ Chlorpheniramine maleate } \\
\hline Conc $\mu \mathrm{g} / \mathrm{ml}$ & Area counts & Conc $\mu \mathrm{g} / \mathrm{ml}$ & Area counts & Conc $\mu \mathrm{g} / \mathrm{ml}$ & Area counts \\
\hline 1.00 & 560581 & 0.60 & 278415 & 0.02 & 190320 \\
\hline 2.50 & 1419062 & 1.50 & 687456 & 0.05 & 487956 \\
\hline 5.00 & 2878887 & 3.00 & 1358742 & 0.10 & 954786 \\
\hline 10.00 & 5602579 & 6.00 & 2786284 & 0.20 & 1923654 \\
\hline 12.50 & 7041847 & 7.50 & 3568745 & 0.25 & 2378462 \\
\hline 15.00 & 8443101 & 9.00 & 4254810 & 0.30 & 2854810 \\
\hline Corr Coef & 0.999 & Corr Coef & 0.999 & Corr Coef & 0.999 \\
\hline Slope & 561966.74 & Slope & 474141.22 & Slope & 9518964.73 \\
\hline Intercepst & 13655.29 & Intercept & 21692.26 & Intercept & 4648.64 \\
\hline
\end{tabular}




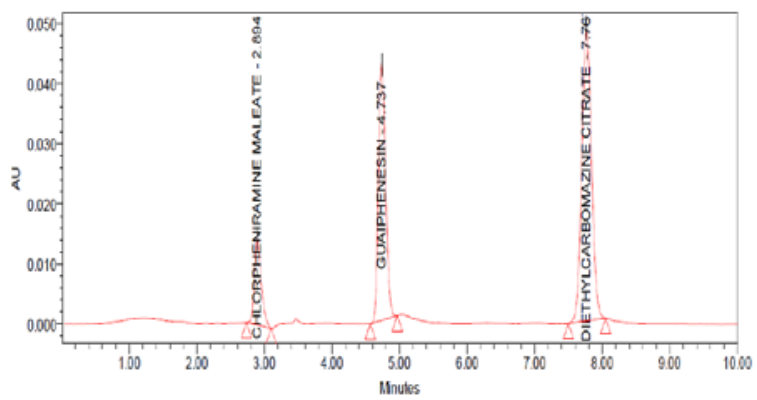

Fig. 6: Chromatogram for linearity-1

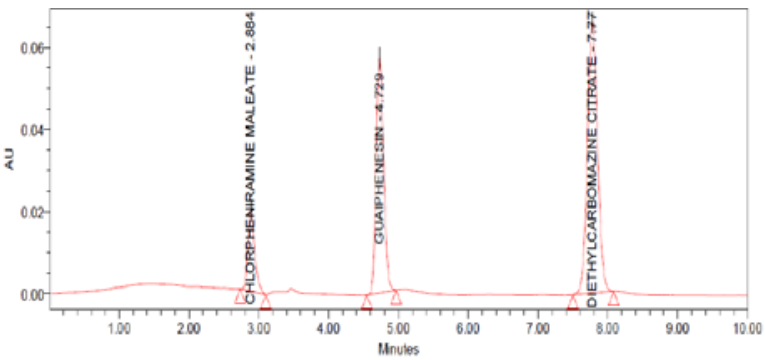

Fig. 7: Chromatogram for linearity-2

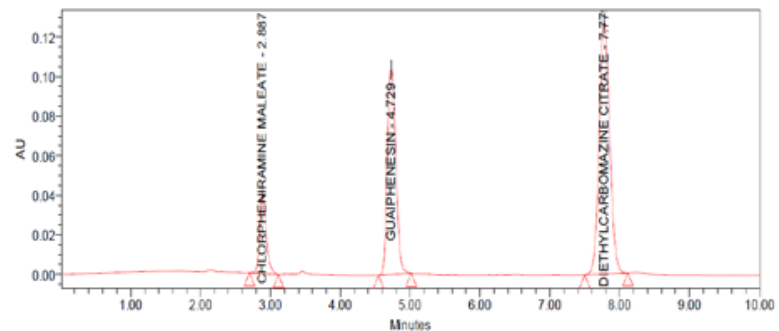

Fig. 8: Chromatogram for linearity-3

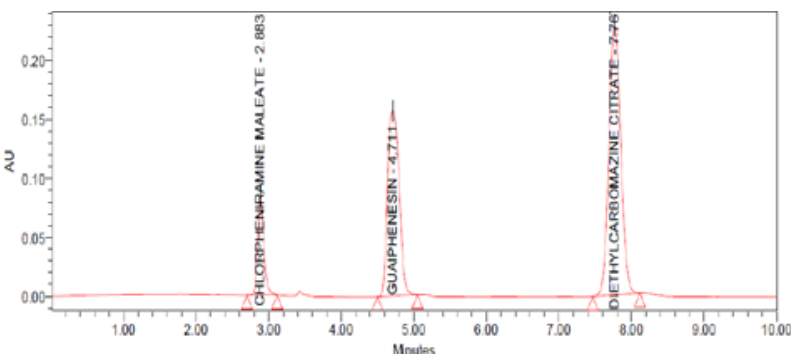

Fig. 9: Chromatogram for linearity-4

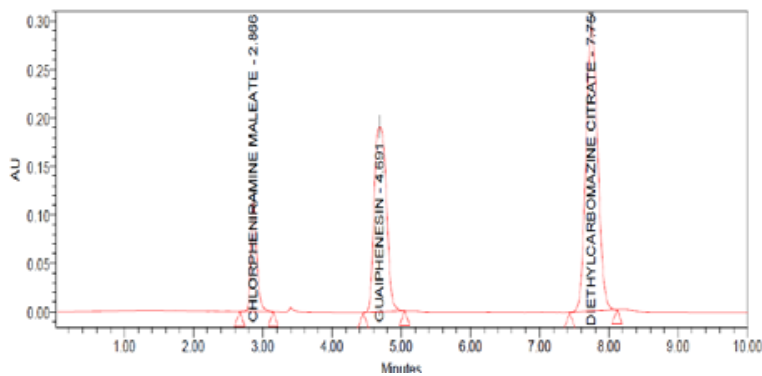

Fig. 10: Chromatogram for linearity-5

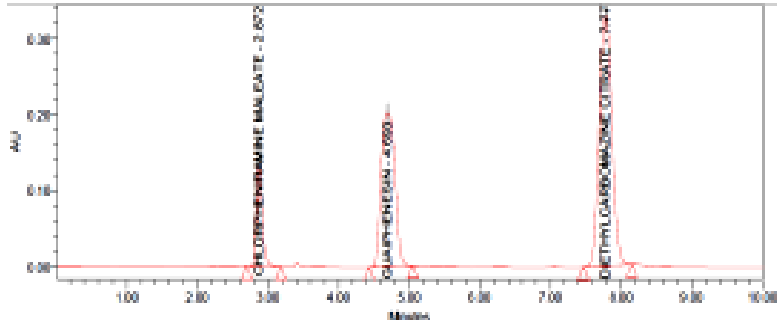

Fig. 11: Chromatogram for linearity-6

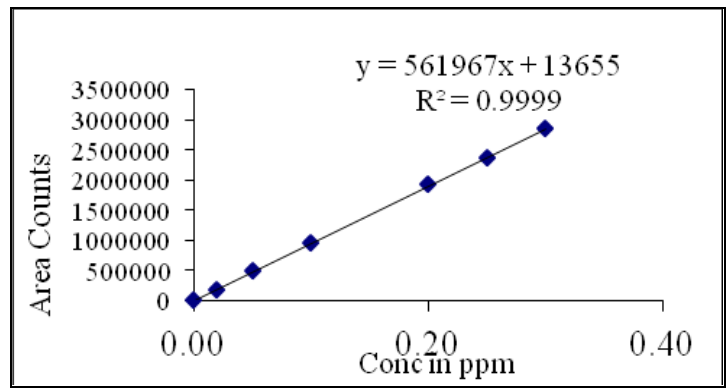

Fig. 12: Linearity plot for diethylcarbamazine citrate

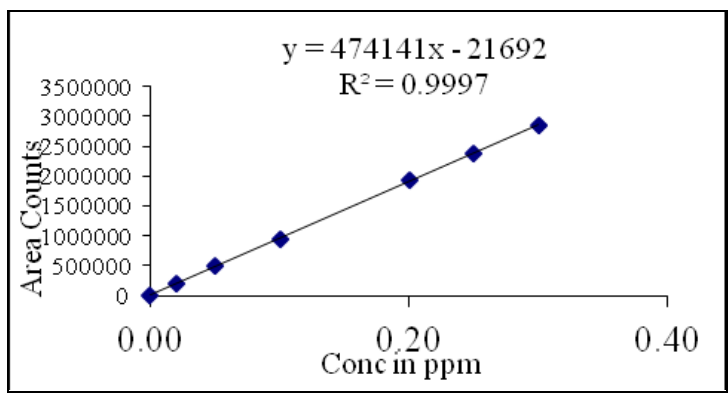

Fig. 13: Linearity plot for guaiphenesin

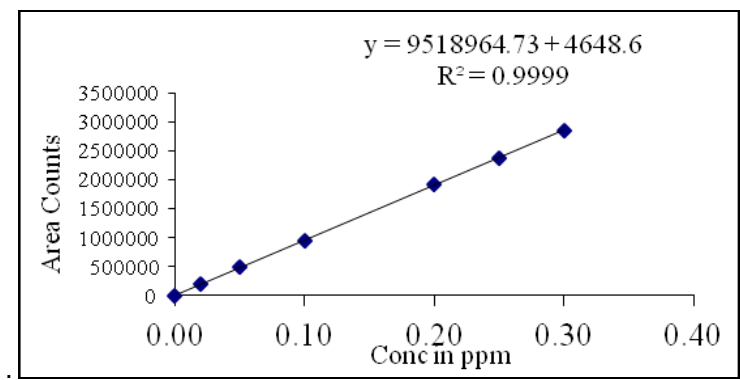

Fig. 14: Linearity plot for chlorpheniramine maleate

\section{Accuracy}

In this method, accuracy was determined by recovery studies which were carried out in three different concentration levels $(50 \%, 100 \%$ and 150\%). APIs with concentration 5, 10 and $15 \mu \mathrm{g} / \mathrm{ml}$ of diethylcarbamazine citrate; 3,6 and $9 \mu \mathrm{g} / \mathrm{ml}$ of guaiphenesin; and 0.1 , 0.2 and $0.3 \mu \mathrm{g} / \mathrm{ml}$ of chlorpheniramine maleate were prepared. As per the test method, the test solution was injected three times for each spike level and the assay was performed. The accuracy and reliability of the developed method were established. The percentage recovery values were found to be in the range of $100.34-100.81 \%$ for diethylcarbamazine citrate and $100.51-100.18 \%$ for guaiphenesin and $100.64-100.34 \%$ for chlorpheniramine maleate. RSD values were found to be less than $2 \%$. The results are given in table 3,4 and 5 . 
Table 3: Accuracy data for diethylcarbamazine citrate

\begin{tabular}{|c|c|c|c|c|c|c|}
\hline Accuracy & $\begin{array}{l}\text { Amount of drug } \\
\text { conc } \mu \mathrm{g} / \mathrm{ml}\end{array}$ & $\begin{array}{l}\text { Amount added } \\
\mu \mathrm{g} / \mathrm{ml}\end{array}$ & $\begin{array}{l}\text { Amount obtained } \\
\mu \mathrm{g} / \mathrm{ml}\end{array}$ & Area counts & \% Recovery & $\begin{array}{l}\text { Mean recovery, } \\
\pm \mathrm{RSD}\end{array}$ \\
\hline \multirow[t]{3}{*}{$50 \%$} & 10.01 & 5.08 & 5.031 & 1383585 & 100.34 & 100.26, \\
\hline & 10.01 & 5.04 & 5.012 & 1379603 & 100.28 & 0.10 \\
\hline & 10.01 & 5.11 & 5.143 & 1313241 & 100.15 & \\
\hline \multirow[t]{3}{*}{$100 \%$} & 10.01 & 10.18 & 10.541 & 2789315 & 100.27 & 100.26, \\
\hline & 10.01 & 10.12 & 10.324 & 2784571 & 100.18 & 0.07 \\
\hline & 10.01 & 10.16 & 10.148 & 2799874 & 100.32 & \\
\hline \multirow[t]{3}{*}{$150 \%$} & 10.01 & 15.47 & 15.478 & 4189106 & 100.24 & 100.5 \\
\hline & 10.17 & 15.28 & 15.369 & 4196329 & 100.45 & 0.28 \\
\hline & 10.17 & 15.19 & 15.214 & 4145316 & 100.81 & \\
\hline
\end{tabular}

Table 4: Accuracy data for guaiphenesin

\begin{tabular}{|c|c|c|c|c|c|c|}
\hline Accuracy & $\begin{array}{l}\text { Amount of drug } \\
\text { conc } \mu \mathrm{g} / \mathrm{ml}\end{array}$ & $\begin{array}{l}\text { Amount added } \\
\mu \mathrm{g} / \mathrm{ml}\end{array}$ & $\begin{array}{l}\text { Amount obtained } \\
\mu \mathrm{g} / \mathrm{ml}\end{array}$ & Area counts & \% Recovery & $\begin{array}{l}\text { Mean recovery, } \\
\pm \mathrm{RSD}\end{array}$ \\
\hline \multirow[t]{3}{*}{$50 \%$} & 6.12 & 3.01 & 3.124 & 904105 & 100.51 & 100.37, \\
\hline & 6.12 & 3.05 & 3.131 & 904979 & 100.35 & 0.12 \\
\hline & 6.12 & 3.14 & 3.214 & 894400 & 100.27 & \\
\hline \multirow[t]{3}{*}{$100 \%$} & 6.12 & 6.15 & 6.528 & 1871153 & 100.38 & 100.45, \\
\hline & 6.12 & 6.21 & 6.374 & 1880820 & 100.47 & 0.07 \\
\hline & 6.12 & 6.28 & 6.484 & 1892189 & 100.52 & \\
\hline \multirow[t]{3}{*}{$150 \%$} & 6.12 & 9.57 & 9.428 & 2847220 & 100.61 & 100.42, \\
\hline & 6.12 & 9.26 & 9.569 & 2867896 & 100.48 & 0.21 \\
\hline & 6.12 & 9.15 & 9.214 & 2816024 & 100.18 & \\
\hline
\end{tabular}

Table 5: Accuracy data for chlorpheniramine maleate

\begin{tabular}{|c|c|c|c|c|c|c|}
\hline Accuracy & $\begin{array}{l}\text { Amount of drug } \\
\text { conc } \mu \mathrm{g} / \mathrm{ml}\end{array}$ & $\begin{array}{l}\text { Amount added } \\
\mu \mathrm{g} / \mathrm{ml}\end{array}$ & $\begin{array}{l}\text { Amount obtained } \\
\mu \mathrm{g} / \mathrm{ml}\end{array}$ & Area counts & \% Recovery & $\begin{array}{l}\text { Mean recovery, } \\
\pm \mathrm{RSD}\end{array}$ \\
\hline \multirow[t]{3}{*}{$50 \%$} & 0.21 & 0.15 & 0.148 & 254967 & 100.64 & 100.49, \\
\hline & 0.21 & 0.14 & 0.142 & 257431 & 100.58 & 0.19 \\
\hline & 0.21 & 0.11 & 0.147 & 252908 & 100.27 & \\
\hline \multirow[t]{3}{*}{$100 \%$} & 0.21 & 0.21 & 0.215 & 547450 & 100.56 & 100.41, \\
\hline & 0.21 & 0.22 & 0.218 & 546146 & 100.38 & 0.13 \\
\hline & 0.21 & 0.23 & 0.223 & 541044 & 100.29 & \\
\hline \multirow[t]{3}{*}{$150 \%$} & 0.21 & 0.30 & 0.347 & 793703 & 100.17 & 100.24, \\
\hline & 0.21 & 0.31 & 0.311 & 792084 & 100.21 & 0.08 \\
\hline & 0.21 & 0.32 & 0.318 & 793544 & 100.34 & \\
\hline
\end{tabular}

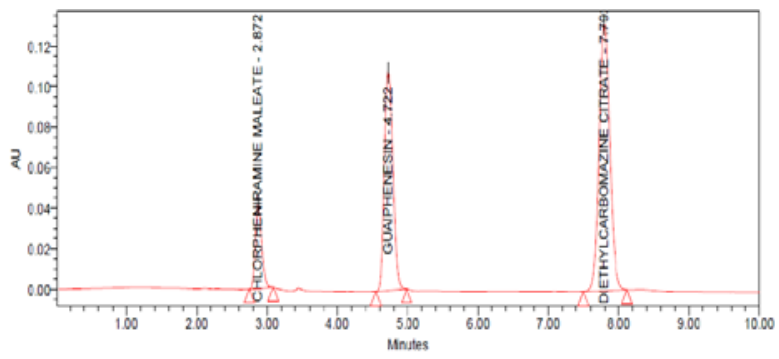

Fig. 15: Chromatogram for accuracy 50\%-1

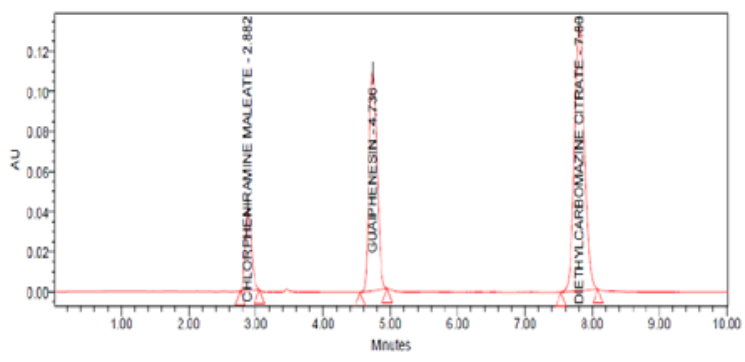

Fig. 16: Chromatogram for accuracy 50\%-2

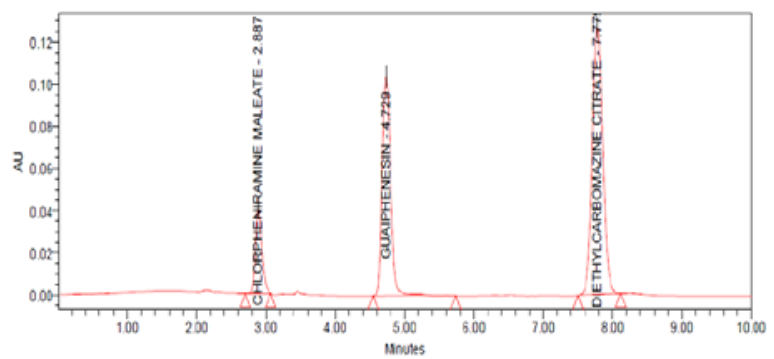

Fig. 17: Chromatogram for accuracy $50 \%-3$

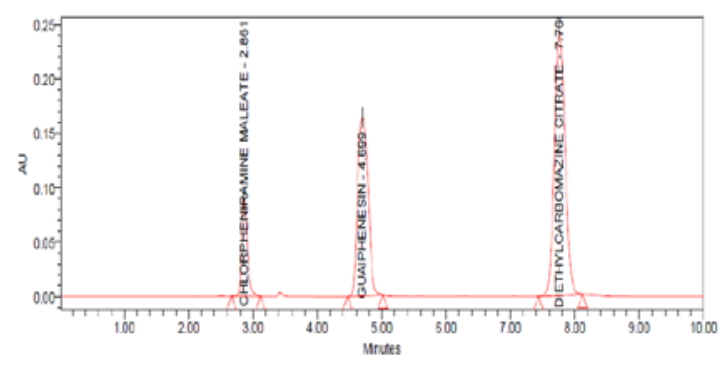

Fig. 18: Chromatogram for accuracy 100\%-1 


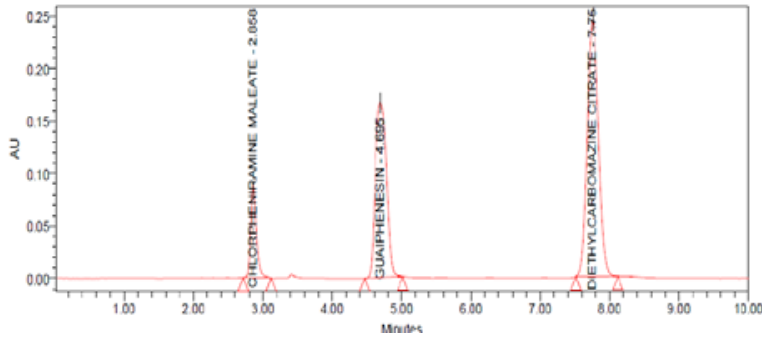

Fig. 19: Chromatogram for accuracy $100 \%-2$

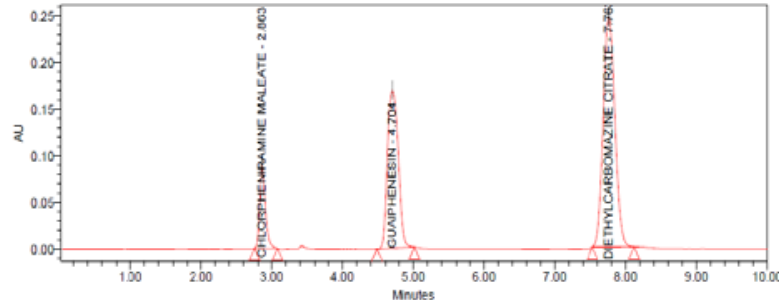

Fig. 20: Chromatogram for accuracy 100\%-3

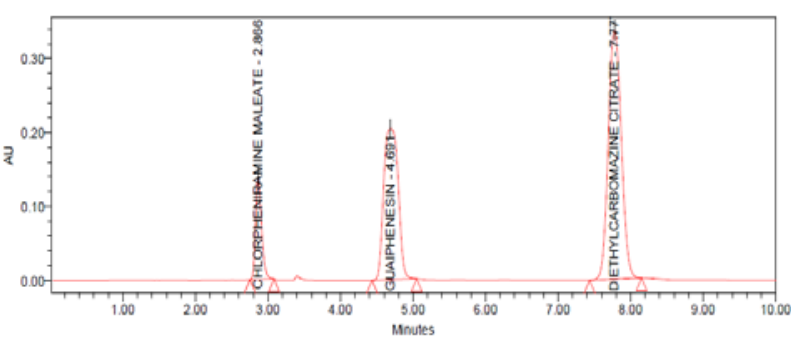

Fig. 21: Chromatogram for accuracy $150 \%-1$

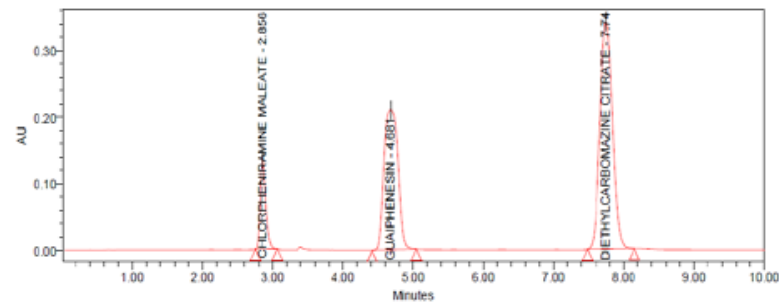

Fig. 22: Chromatogram for accuracy $150 \%-2$

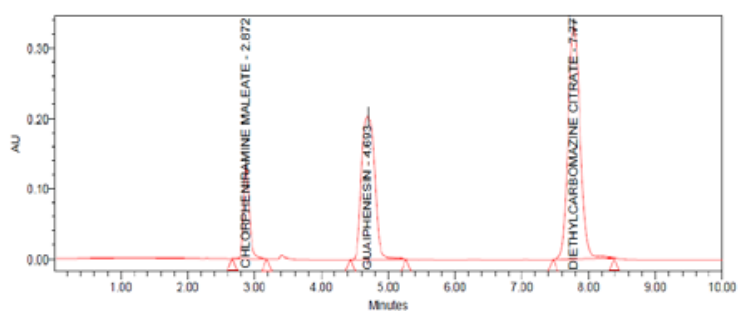

Fig. 23: Chromatogram for accuracy $150 \%-3$

\section{Precision}

Repeatability

Repeatability was calculated by injecting standard solution six times containing diethylcarbamazine citrate $(10 \mu \mathrm{g} / \mathrm{ml})$, guaiphenesin $(6 \mu \mathrm{g} / \mathrm{ml})$ and chlorpheniramine maleate $(0.2 \mu \mathrm{g} / \mathrm{ml})$. Peak areas and $\%$ RSD were calculated.

\section{Intraday precision}

Six replicates of a sample solution containing diethylcarbamazine citrate $(10 \mu \mathrm{g} / \mathrm{ml})$, guaiphenesin $(6 \mu \mathrm{g} / \mathrm{ml})$ and chlorpheniramine maleate $(0.2 \mu \mathrm{g} / \mathrm{ml})$ were analysed on the same day. Peak areas were calculated, which were used to calculate mean, SD and \%RSD values.

\section{Interday precision}

Six replicates of a sample solution containing diethylcarbamazine citrate $(10 \mu \mathrm{g} / \mathrm{ml})$, guaiphenesin $(6 \mu \mathrm{g} / \mathrm{ml})$, and chlorpheniramine maleate $(0.2 \mu \mathrm{g} / \mathrm{ml})$ were analysed on a different day. Peak areas were calculated which were used to calculate mean, SD and \%RSD values. The present method was found to be precise as the RSD values were less than $2 \%$ and also the percentage assay values were close to be $100 \%$. The results are given in table 6 and 7 .

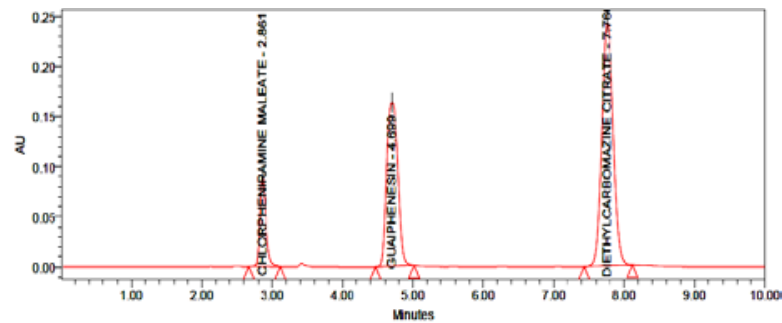

Fig. 24: Chromatogram for method precision-1

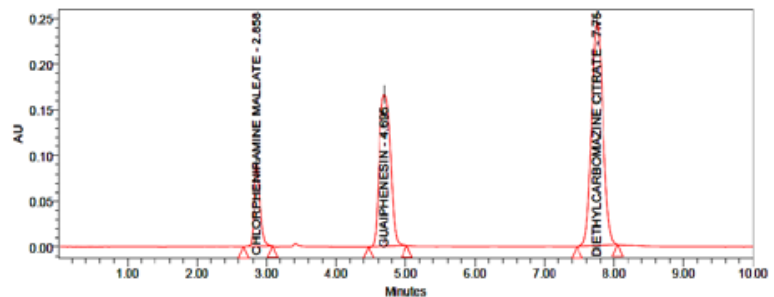

Fig. 25: Chromatogram for method precision-2

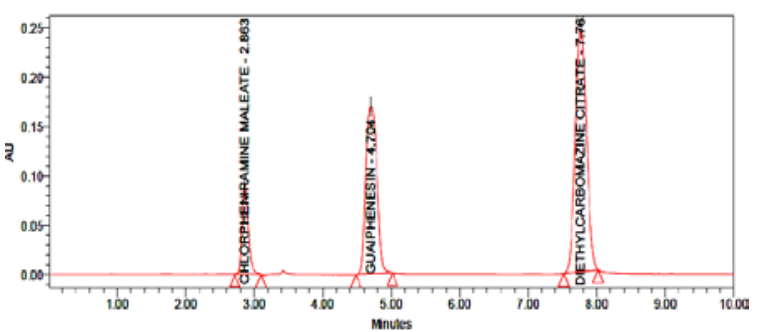

Fig. 26: Chromatogram for method precision-3

Table 6: Intraday data for diethylcarbamazine citrate, guaiphenesin and chlorpheniramine maleate

\begin{tabular}{|c|c|c|c|c|c|c|c|c|}
\hline \multicolumn{3}{|c|}{ Diethylcarbamazine citrate } & \multicolumn{3}{|c|}{ Guaiphenesin } & \multicolumn{3}{|c|}{ Chlorpheniramine maleate } \\
\hline Conc $(\mu \mathrm{g} / \mathrm{ml})$ & Area counts & $\%$ assay as is & Conc $(\mu \mathrm{g} / \mathrm{ml})$ & Area counts & $\%$ assay as is & Conc $(\mu \mathrm{g} / \mathrm{ml})$ & Area counts & $\%$ assay as is \\
\hline \multirow[t]{6}{*}{10.0} & 2789315 & 100.42 & 6.0 & 1871153 & 100.68 & 0.2 & 547450 & 100.25 \\
\hline & 2788941 & 100.68 & & 1880820 & 100.54 & & 541665 & 100.37 \\
\hline & 2764650 & 100.54 & & 1892189 & 100.42 & & 549553 & 100.48 \\
\hline & 2790843 & 100.28 & & 1892461 & 100.37 & & 546337 & 100.51 \\
\hline & 2789315 & 100.64 & & 1871153 & 100.26 & & 547450 & 100.68 \\
\hline & 2789421 & 100.37 & & 1892189 & 100.15 & & 545149 & 100.75 \\
\hline$\%$ RSD & 1.66 & & 0.67 & & & 0.49 & & \\
\hline
\end{tabular}


Table 7: Interday data for diethylcarbamazine citrate, guaiphenesin and chlorpheniramine maleate

\begin{tabular}{|c|c|c|c|c|c|c|c|c|}
\hline \multicolumn{3}{|c|}{ Diethylcarbamazine citrate } & \multicolumn{3}{|l|}{ Guaiphenesin } & \multicolumn{3}{|c|}{ Chlorpheniramine maleate } \\
\hline Conc $(\mu \mathrm{g} / \mathrm{ml})$ & Area counts & $\begin{array}{l}\text { \% assay } \\
\text { as is }\end{array}$ & Conc $(\mu \mathrm{g} / \mathrm{ml})$ & Area counts & $\begin{array}{l}\text { \% assay } \\
\text { as is }\end{array}$ & Conc $(\mu \mathrm{g} / \mathrm{ml})$ & Area counts & $\begin{array}{l}\text { \% assay } \\
\text { as is }\end{array}$ \\
\hline \multirow[t]{6}{*}{10.0} & 2764851 & 100.56 & 6.0 & 1841523 & 100.43 & 0.2 & 541282 & 100.38 \\
\hline & 2758945 & 100.37 & & 1847456 & 100.68 & & 541365 & 100.56 \\
\hline & 2768748 & 100.41 & & 1848752 & 100.36 & & 541878 & 100.37 \\
\hline & 2775358 & 100.52 & & 1845896 & 100.38 & & 541758 & 100.58 \\
\hline & 2787486 & 100.78 & & 1847893 & 100.55 & & 541785 & 100.41 \\
\hline & 2778952 & 100.54 & & 1847895 & 100.47 & & 541478 & 100.36 \\
\hline \% RSD & 0.84 & & 0.73 & & & 0.68 & & \\
\hline
\end{tabular}

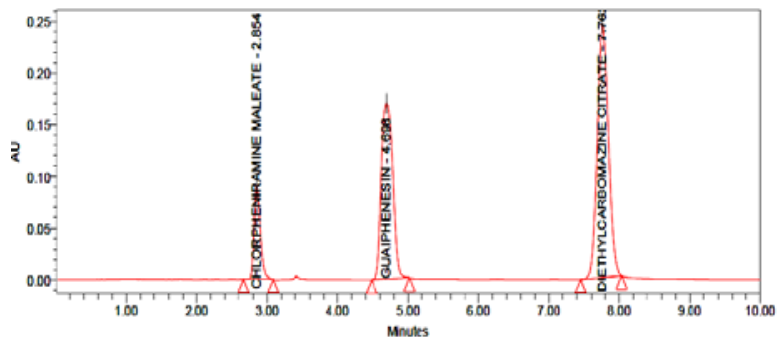

Fig. 27: Chromatogram for method precision-4

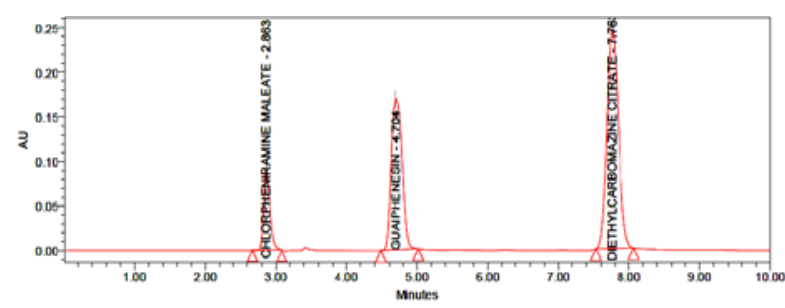

Fig. 28: Chromatogram for method precision-5

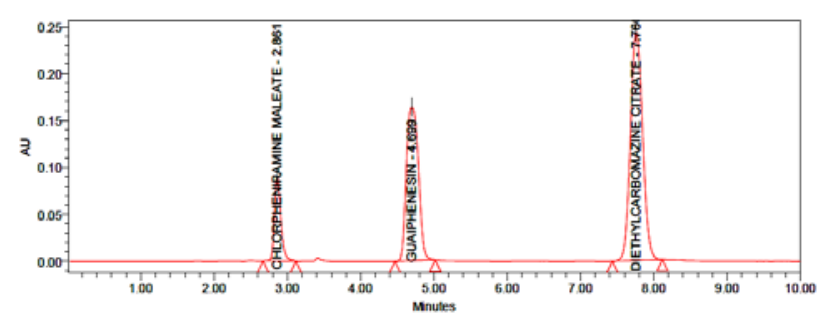

Fig. 29: Chromatogram for method precision-6

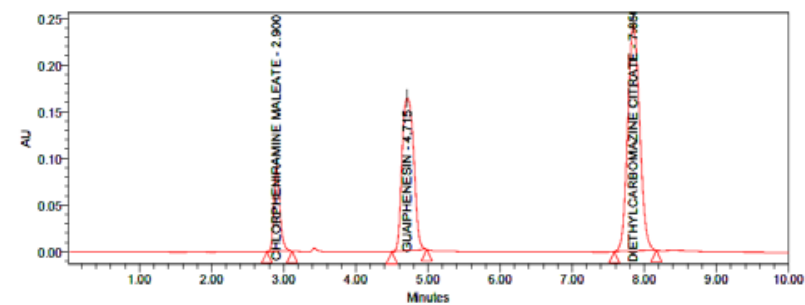

Fig. 30: Chromatogram for intermediate precision-1

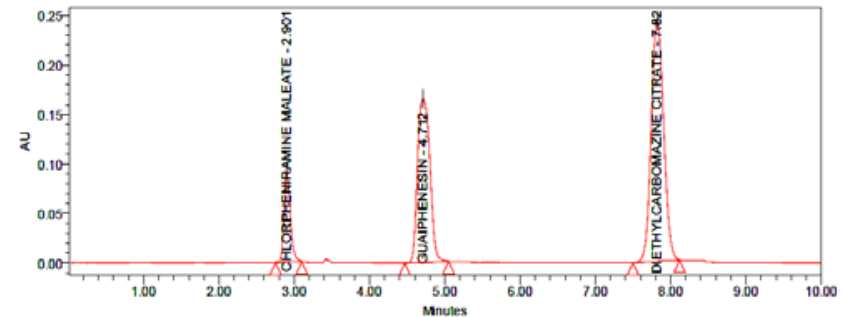

Fig. 31: Chromatogram for intermediate precision-2

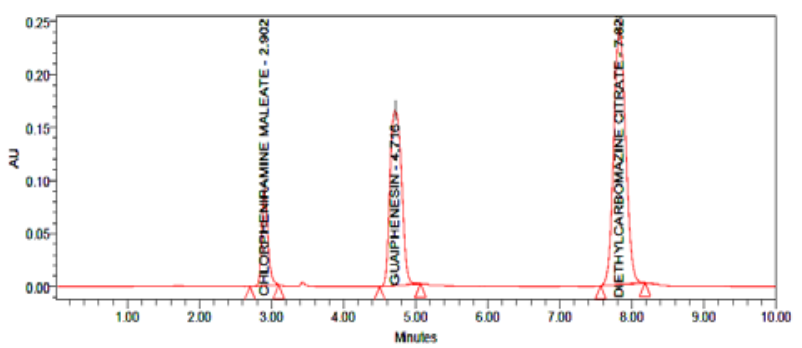

Fig. 32: Chromatogram for intermediate precision-3

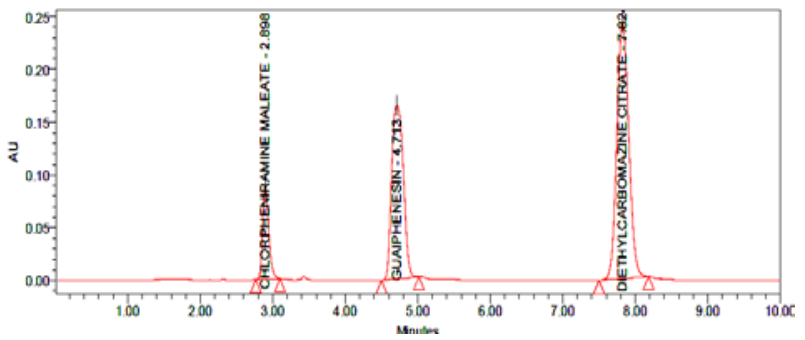

Fig. 33: Chromatogram for intermediate precision-4

\section{LOD and LOQ}

LOD and LOQ minimum concentration level at which the analyte can be reliably detected, quantified by using the standard formulas (3.3times $\sigma / \mathrm{s}$ and 10times $\sigma / \mathrm{s}$ for LOD and LOQ respectively) were found to be 0.1 and $0.2 \mu \mathrm{g} / \mathrm{ml}$ for diethylcarbamazine citrate, 0.06 and $0.12 \mu \mathrm{g} / \mathrm{ml}$ for guaiphenesin and 0.002 and $0.004 \mu \mathrm{g} / \mathrm{ml}$ for chlorpheniramine maleate. The low values of LOD and LOQ indicate the high sensitivity of method. The results are given in table 8 and 9 .

Table 8: Results of LOQ

\begin{tabular}{lllll}
\hline Diethylcarbamazinecitrate & & Guaiphenesin & Chlorpheniramine maleate \\
\hline Conc $(\mu \mathrm{g} / \mathbf{m l})$ & $\mathbf{s} / \mathbf{n}$ & Conc $(\mu \mathrm{g} / \mathbf{m l})$ & $\mathbf{s} / \mathbf{n}$ & Conc $(\boldsymbol{\mu g} / \mathbf{m l})$ \\
\hline 0.2 & 17 & 0.12 & 15 & 0.004 \\
\hline
\end{tabular}


Table 9: Results of LOD

\begin{tabular}{lllll}
\hline Diethylcarbamazine citrate & & Guaiphenesin & Chlorpheniramine maleate \\
\hline Conc $(\mu \mathrm{g} / \mathrm{ml})$ & $\mathbf{s} / \mathbf{n}$ & Conc $(\mu \mathrm{g} / \mathbf{m l})$ & $\mathbf{s} / \mathbf{n}$ & Conc $(\mu \mathrm{g} / \mathbf{m l})$ \\
\hline 0.1 & 5 & 0.06 & 4 & 0.002 \\
\hline
\end{tabular}

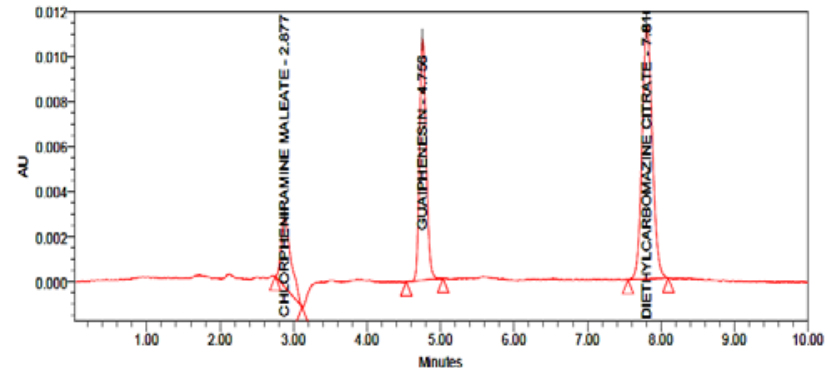

Fig. 36: Chromatogram for LOD

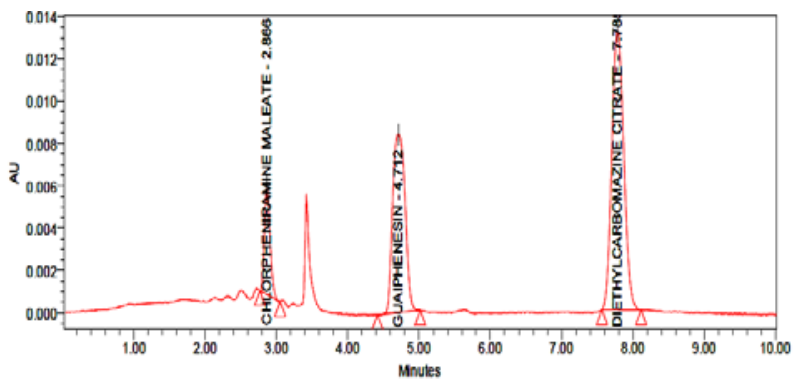

Fig. 37: Chromatogram for LOQ

\section{Forced degradation}

Stress degradation conditions such as acidic, basic, oxidative, reduction, thermal, hydrolysis and photolytic stresses were attempted as per ICH guidelines Q1A (R2).

\section{Acid degradation}

Acid degradation studies were carried out by weighing $27 \mathrm{mg}$ of sample and transferred to a $10 \mathrm{ml}$ volumetric flask, to this add 5 $\mathrm{ml}$ of diluent dissolve it and add $0.1 \mathrm{ml}$ of $5 \mathrm{~N} \mathrm{HCl}$. The mixture was refluxed at $70{ }^{\circ} \mathrm{C}$ for 1 hour. Then the solution was neutralized with $0.1 \mathrm{ml}$ of $5 \mathrm{~N} \mathrm{NaOH}$ and diluted with the mobile phase up to the mark and mixed well. $0.1 \mathrm{ml}$ of the same solution was diluted to $10 \mathrm{ml}$ with the diluent. $10 \mu \mathrm{l}$ of the above solution was injected into the HPLC system and chromatograms were recorded.

\section{Alkali degradation}

Alkali degradation studies were carried out by weighing $27 \mathrm{mg}$ of sample and transferred to a $10 \mathrm{ml}$ volumetric flask, to this add $5 \mathrm{ml}$ of diluent dissolve it and add $0.1 \mathrm{ml}$ of $5 \mathrm{~N} \mathrm{NaOH}$. The mixture was refluxed at $70{ }^{\circ} \mathrm{C}$ for 1 hour. Then the solution was neutralized with $0.1 \mathrm{ml}$ of $5 \mathrm{~N} \mathrm{HCl}$ and diluted with the mobile phase up to the mark and mixed well. $0.1 \mathrm{ml}$ of the same solution was diluted to $10 \mathrm{ml}$ with the diluent. $10 \mu \mathrm{l}$ of the above solution was injected into the system and chromatograms were recorded.

\section{Peroxide degradation}

Peroxide degradation studies were carried out by weighing $27 \mathrm{mg}$ of sample and transferred to a $10 \mathrm{ml}$ volumetric flask, to this add $5 \mathrm{ml}$ of diluent dissolve it and add $0.1 \mathrm{ml}$ of $15 \% \mathrm{H}_{2} \mathrm{O}_{2}$. The mixture was refluxed at $70{ }^{\circ} \mathrm{C}$ for $30 \mathrm{~min} .1 \mathrm{ml}$ of the same solution was diluted to $10 \mathrm{ml}$ with the diluent. $10 \mu \mathrm{l}$ of the above solution was injected into the system and chromatograms were recorded.

\section{Reduction degradation}

Reduction degradation studies were carried out by weighing $27 \mathrm{mg}$ of sample and transferred to a $10 \mathrm{ml}$ volumetric flask, to this add 5 $\mathrm{ml}$ of diluent dissolve it and add $0.1 \mathrm{ml}$ of $10 \%$ sodium bisulphate. The mixture was refluxed at $70{ }^{\circ} \mathrm{C}$ for 1 hour. $0.1 \mathrm{ml}$ of the same solution was diluted to $10 \mathrm{ml}$ with the diluent. $10 \mu \mathrm{l}$ of the above solution was injected into the system and chromatograms were recorded.

\section{Hydrolysis degradation:}

Hydrolysis degradation studies were carried out by weighing 27 $\mathrm{mg}$ of sample and transferred to a $10 \mathrm{ml}$ volumetric flask, to this add $5 \mathrm{ml}$ of diluent and add $0.1 \mathrm{ml}$ of water and sonicated to disperse, dissolve and refluxed at $70^{\circ} \mathrm{C}$ for $30 \mathrm{~min} .0 .1 \mathrm{ml}$ of the same solution was diluted to $10 \mathrm{ml}$ with the diluent. $10 \mu \mathrm{l}$ of the above solution was injected into the system and chromatograms were recorded.

\section{Thermal degradation}

Thermal degradation studies were carried out by weighing 27 mg of sample and exposed to a temperature of $80^{\circ} \mathrm{C}$ for $72 \mathrm{~h}$ in hot air oven. Then the sample was transferred to a $10 \mathrm{ml}$ volumetric flask, dissolves in $5 \mathrm{ml}$ of diluent and diluted with mobile phase up to the mark. $1 \mathrm{ml}$ of the same solution was diluted to $10 \mathrm{ml}$ with the diluent. $10 \mu \mathrm{l}$ of the above solution was injected into the system and chromatograms were recorded.

\section{Photolytic degradation}

Photolytic degradation studies were carried out by weighing 27 $\mathrm{mg}$ of sample and exposed to 1.2 Million lux hours of light. Then the sample was transferred to a $10 \mathrm{ml}$ volumetric flask, dissolved in $5 \mathrm{ml}$ of diluent and diluted with the mobile phase up to the mark. $1 \mathrm{ml}$ of the same solution was diluted to $10 \mathrm{ml}$ with the diluent.10 $\mu \mathrm{l}$ of the above solution was injected into the system and chromatograms were recorded.

Table 10: Results of force degradation studies of diethylcarbamazine citrate

\begin{tabular}{|c|c|c|c|c|c|}
\hline Stress condition & Time & \% assay & \% degradation & Purity angle & Purity threshold \\
\hline Acid degradation & $1 \mathrm{~h}$ & 86.8 & 13.2 & 0.12 & 0.25 \\
\hline Alkaline degradation & $1 \mathrm{~h}$ & 94.8 & 5.2 & 0.14 & 0.28 \\
\hline Oxidative degradation & $30 \mathrm{~min}$ & 96.5 & 3.5 & 0.18 & 0.24 \\
\hline Reduction degradation & $1 \mathrm{~h}$ & 93.6 & 6.4 & 0.16 & 0.30 \\
\hline Thermal degradation & $3 \mathrm{~h}$ & 87.2 & 12.8 & 0.14 & 0.28 \\
\hline Photolytic degradation & $72 \mathrm{~h}$ & 84.9 & 15.1 & 0.11 & 0.25 \\
\hline Hydrolysis degradation & $30 \mathrm{~min}$ & 91.1 & 8.9 & 0.15 & 0.24 \\
\hline
\end{tabular}


Table 11: Results of force degradation studies of guaiphenesin

\begin{tabular}{llllll}
\hline Stress condition & Time & \% assay & \% degradation & Purity angle & Purity threshold \\
\hline Acid degradation & $1 \mathrm{~h}$ & 85.4 & 14.6 & 0.10 & 0.27 \\
Alkaline degradation & $1 \mathrm{~h}$ & 93.6 & 6.4 & 0.17 & 0.32 \\
Oxidative degradation & $30 \mathrm{~min}$ & 95.3 & 4.7 & 0.23 & 0.37 \\
Reduction degradation & $1 \mathrm{~h}$ & 92.7 & 7.3 & 0.24 & 0.25 \\
Thermal degradation & $3 \mathrm{~h}$ & 86.5 & 13.5 & 0.16 & 0.45 \\
Photolytic degradation & $72 \mathrm{~h}$ & 84.2 & 15.8 & 0.18 & 0.28 \\
Hydrolysis degradation & $30 \mathrm{~min}$ & 91.8 & 8.2 & & 0.39 \\
\hline
\end{tabular}

Table 12: Results of force degradation studies of chlorpheniramine maleate

\begin{tabular}{llllll}
\hline Stress condition & Time & \% assay & \% degradation & Purity angle & Purity threshold \\
\hline Acid degradation & $1 \mathrm{~h}$ & 85.4 & 13.7 & 0.14 & 0.34 \\
Alkaline degradation & $1 \mathrm{~h}$ & 93.6 & 5.8 & 0.17 & 0.36 \\
Oxidative degradation & $30 \mathrm{~min}$ & 95.3 & 4.2 & 0.39 & 0.19 \\
Reduction Degradation & $1 \mathrm{~h}$ & 92.7 & 12.8 & 0.23 \\
Thermal degradation & $3 \mathrm{~h}$ & 86.5 & 16.4 & 0.18 \\
Photolytic Degradation & $72 \mathrm{~h}$ & 84.2 & 9.4 & 0.41 \\
Hydrolysis Degradation & $30 \mathrm{~min}$ & 91.8 & & 0.43 \\
\hline
\end{tabular}

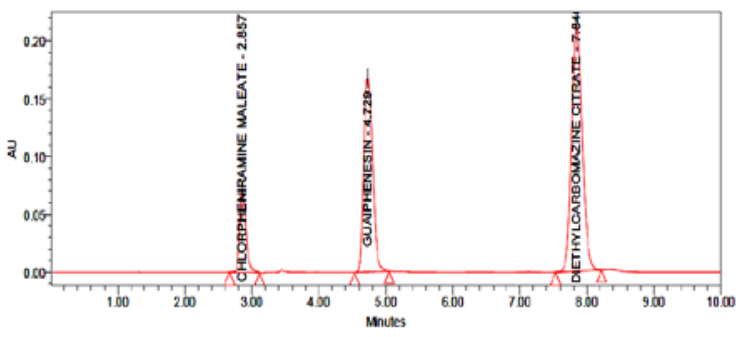

Fig. 38: Chrom for acid degradation

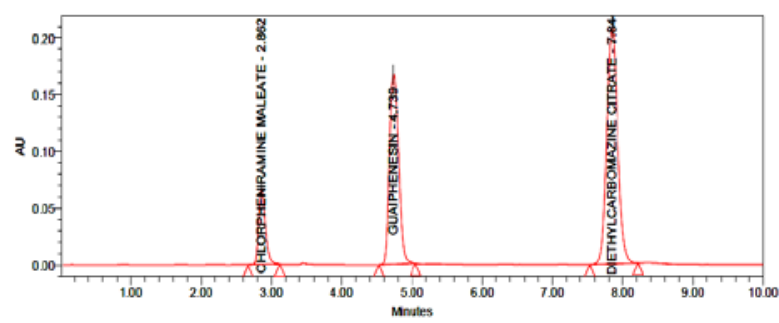

Fig. 39: Chrom for alkali degradation

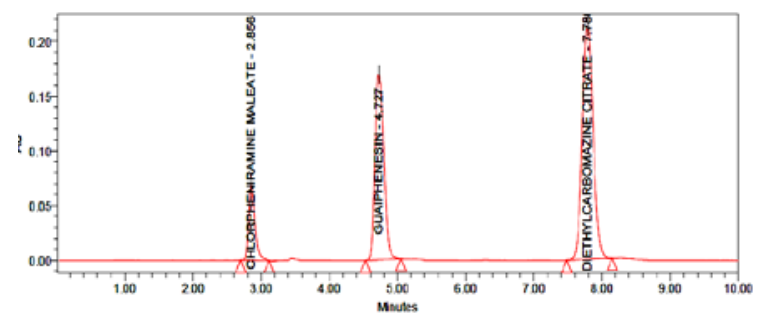

Fig. 40: Chrom for peroxide degradation

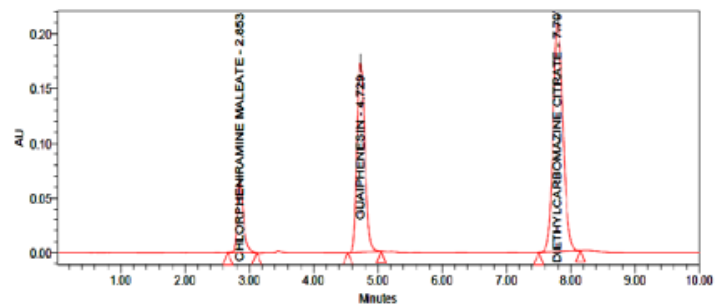

Fig. 41: Chrom for reduction degradation

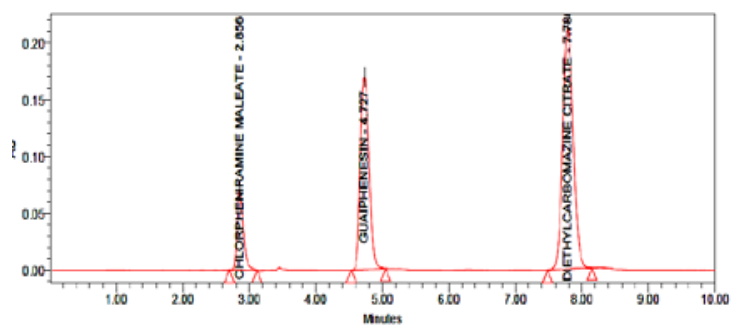

Fig. 42: Chrom for thermal degradation

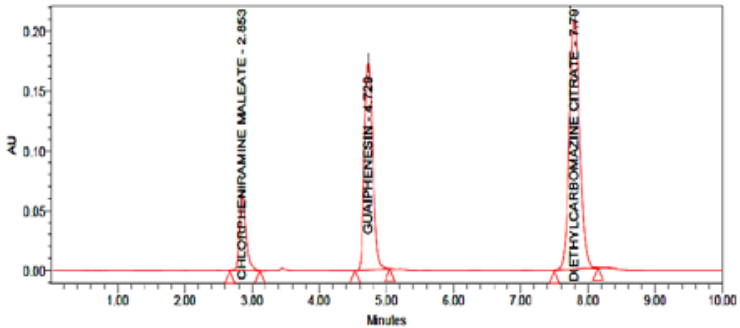

Fig. 43: Chrom for photolytic degradation

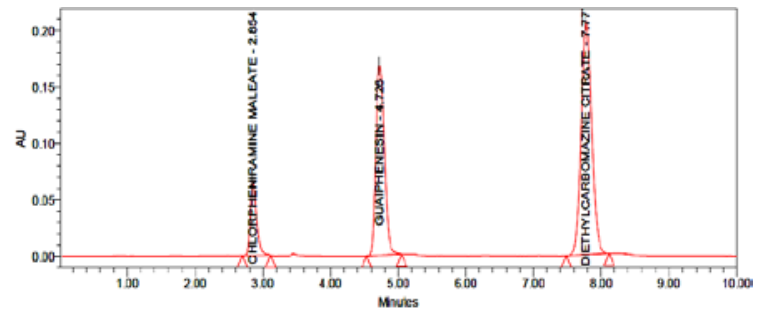

Fig. 44: Chrom for hydrolysis degradation

Robustness

The proposed method was found to be Robust as the \% RSD was found to be less than $2 \%$. Slight variations were done in the optimised method parameters like flow rate $( \pm 0.2 \%)$, organic content in mobile phase $( \pm 5 \%), \mathrm{pH}( \pm 0.2)$ and wavelength of detection $( \pm 5 \%)$.

\section{Flow rate variation}

This study was conducted to find the effect of variation in flow rate. Standard and check standard solutions were prepared as per test 
method and injected into HPLC system with a flow rate of 1.0 $\mathrm{ml} / \mathrm{min}$. System suitability parameters were evaluated and found to be within the specified limits as per test method and RT of the main peak was monitored.

\section{Organic phase variation}

This study was conducted to find the effect of variation in organic phase. Standard and check standard solutions were prepared as per the test method and injected into HPLC system with mobile phases of $0.1 \%$ triethylamine as a buffer along with orthophosphoric acid adjusted to $\mathrm{P}^{\mathrm{H}}$ 2.5: acetonitrile(50:50v/v) and wavelength of 210 $\mathrm{nm}$. System suitability parameters are found to be within the specified limits and RT of the main peak was monitored for 50:50 $\mathrm{v} / \mathrm{v}$ (mixed $0.1 \%$ triethylamine buffer).

\section{PH variation}

This study was conducted to find the variation in $\mathrm{P}^{\mathrm{H}}$. Standard and check standard solutions were prepared as per test method and injected into HPLC system with different buffer $\mathrm{P}^{\mathrm{H}}$. System suitability parameters were evaluated and found to be within the specified limits as per test method and RT of the main peak was monitored.

\section{Wavelength variation}

This study was conducted to find the effect of variation in wavelength. Standard and check standard solutions were prepared as per test method and injected into HPLC system with different buffer wavelengths. System suitability parameters were evaluated and found to be within the specified limits as per test method and RT of the main peak was monitored.

Table 13: Results for robustness

\begin{tabular}{|c|c|c|c|c|c|c|}
\hline \multirow[t]{2}{*}{ Parameter } & \multicolumn{2}{|c|}{ Diethylcarbamazine citrate } & \multicolumn{2}{|l|}{ Guaiphenesin } & \multicolumn{2}{|c|}{ Chlorpheniramine maleate } \\
\hline & USP plate count & USP tailing & USP plate count & USP tailing & USP plate count & USP tailing \\
\hline Less flow rate $(0.8 \mathrm{ml} / \mathrm{min})$ & 3200 & 0.86 & 4320 & 0.08 & 5896 & 0.14 \\
\hline High flow rate $(1.2 \mathrm{ml} / \mathrm{min})$ & 3450 & 0.78 & 3548 & 0.12 & 4100 & 0.11 \\
\hline Less wavelength $(205 \mathrm{~nm})$ & 3525 & 0.45 & 3896 & 0.45 & 4752 & 0.86 \\
\hline High Wavelength (215 nm) & 4272 & 0.52 & 3868 & 0.53 & 5962 & 0.86 \\
\hline Less organic phase composition $(-5 \%)$ & 3984 & 0.68 & 3796 & 0.63 & 4635 & 0.86 \\
\hline High organic phase composition $(+5 \%)$ & 3582 & 0.67 & 3863 & 0.45 & 3785 & 0.86 \\
\hline Less $\mathrm{pH}$ variation $(-0.2)$ & 3985 & 0.73 & 3981 & 0.58 & 3868 & 0.86 \\
\hline High $\mathrm{pH}$ variation $(+0.2)$ & 4584 & 0.59 & 3789 & 0.67 & 4589 & 0.86 \\
\hline
\end{tabular}

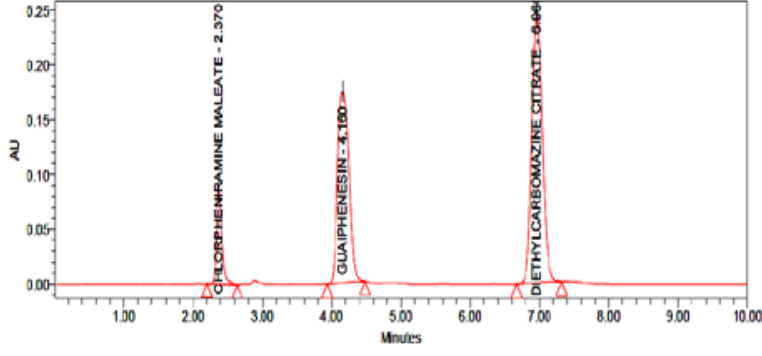

Fig. 45: Chromatogram for flow plus

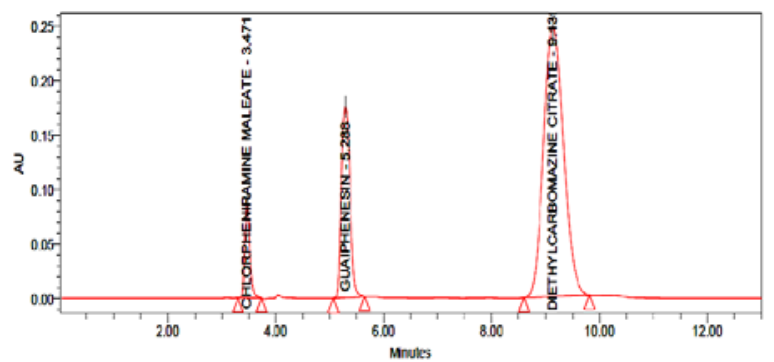

Fig. 46: Chromatogram for flow minus

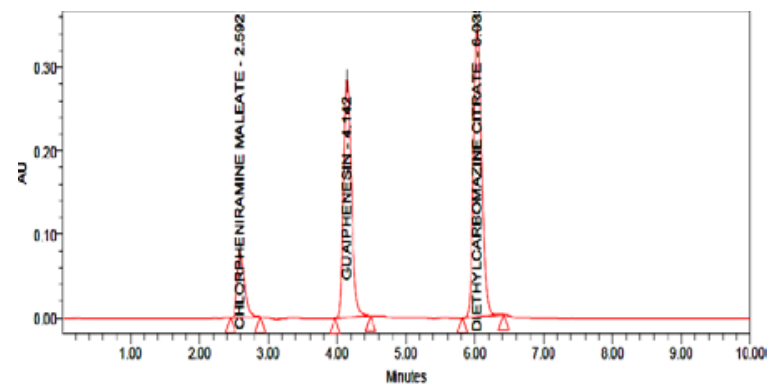

Fig. 47: Chromatogram for org plus

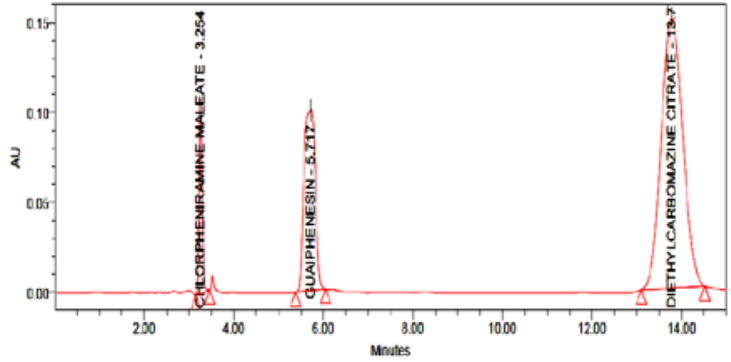

Fig. 48: Chromatogram for org minus

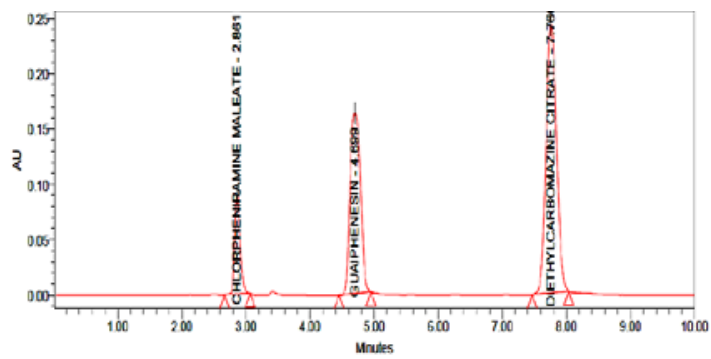

Fig. 49: Chromatogram for wave plus

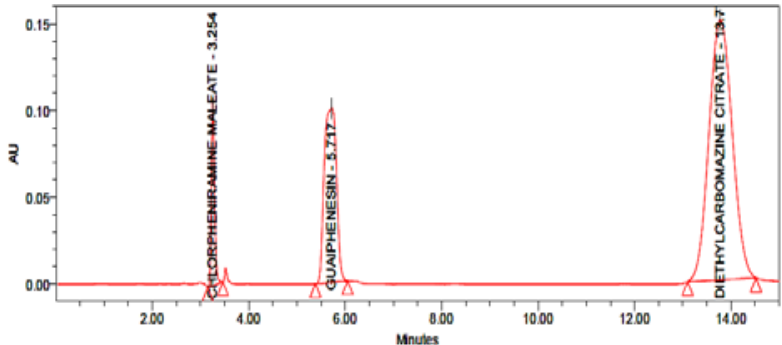

Fig. 50: Chromatogram for wave minus 


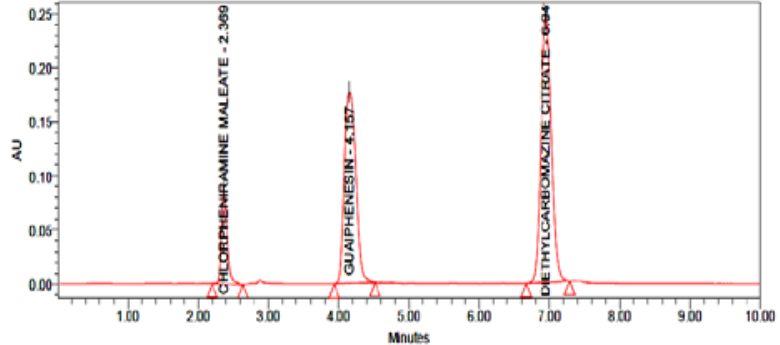

Fig. 51: Chromatogram for $\mathrm{pH}$ plus

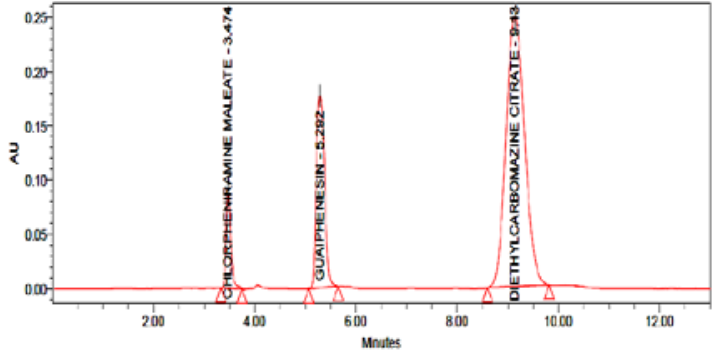

Fig. 52: Chromatogram for $\mathrm{pH}$ minus

Table 14: Results of stability studies

\begin{tabular}{lcc}
\hline Stability & \% assay & \% deviation \\
\hline Initial & 100.2 & 0.00 \\
$6 \mathrm{~h}$ & 100.8 & 0.06 \\
$12 \mathrm{~h}$ & 100.4 & 0.02 \\
$18 \mathrm{~h}$ & 100.3 & 0.01 \\
$24 \mathrm{~h}$ & 100.5 & 0.03 \\
\hline
\end{tabular}

\section{Solution stability}

Sample solutions were analysed initially to $24 \mathrm{~h}$ at different intervals of time at room temperature and the results were recorded. The \% deviation should not be more than $5.0 \%$. The results are given in table 14 .

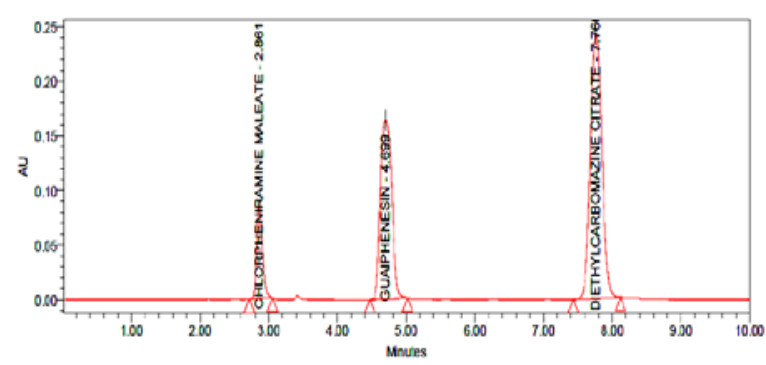

Fig. 53: Chromatogram for stability initial

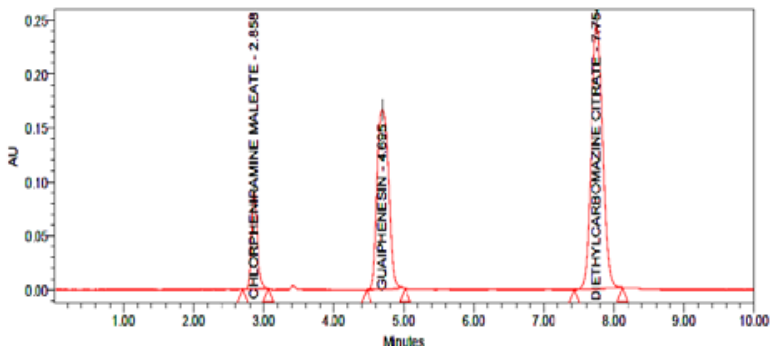

Fig. 54: Chromatogram for stability $6 \mathrm{~h}$

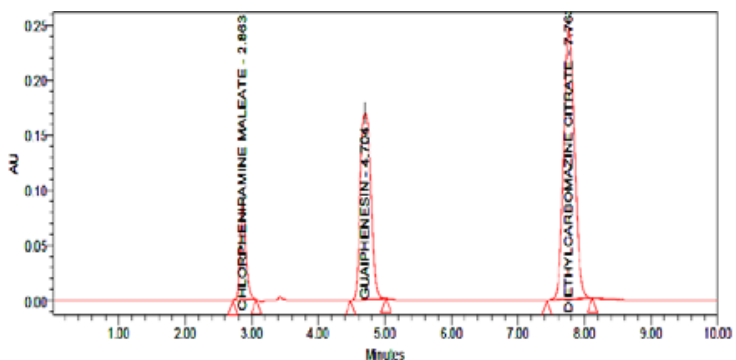

Fig. 55: Chromatogram for stability $12 \mathrm{~h}$

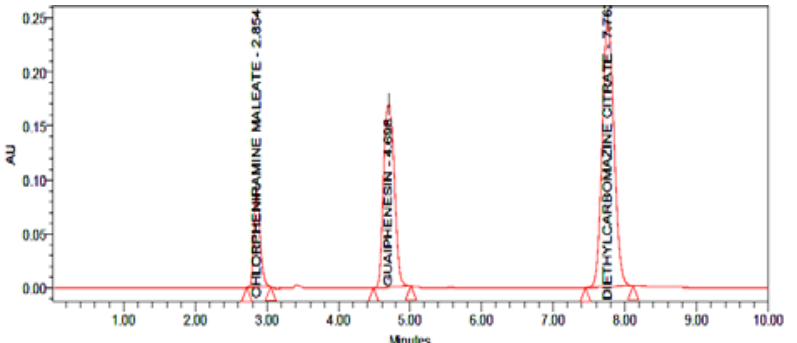

Fig. 56: Chromatogram for stability $18 \mathrm{~h}$

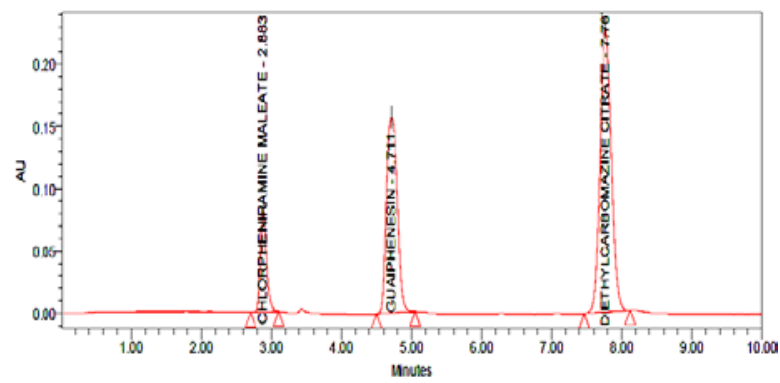

Fig. 57: Chromatogram for stability $24 \mathrm{~h}$

\section{CONCLUSION}

Stability indicating RP-HPLC method was developed and validated for the simultaneous estimation of diethylcarbamazine citrate, guaiphenesin and chlorpheniramine maleate in pharmaceutical formulations as per ICH guidelines. The developed method was found to be accurate, precise and reliable with \%RSD less than $2 \%$. Therefore, the developed method is simple, accurate, precise and robust. The present method was found to be stability indicating as the degradation of drug substance was between $5-20 \%$. Finally, this method can be used for better analysis of pharmaceutical formulations of diethylcarbamazine citrate, guaiphenesin and chlorpheniramine maleate drug.

\section{AUTHORS CONTRIBUTIONS}

All the authors have contributed equally.

\section{CONFLICT OF INTERESTS}

Declared none 


\section{REFERENCES}

1. http://en.wikipedia.org/wiki/Diethylcarbamazine; 2009. [Last accessed on 20 Jul 2017].

2. WHO. Model List of Essential Medicines. World Health Organization; 2013.

3. Indian pharmacopoeia, Ghaziabad, Indian Pharmacopoeia; 2007. p. 558-59, 1005-6.

4. British Pharmacopoeia. London; British Pharmacopoeia Commission; 2009. p. 2861, 5094

5. Indian Pharmacopoeia. The Indian pharmacopoeia commission Ghaziabad, Govt. of India. Ministry of health and Family Welfare. Vol. II; 2007. p. 919-20, 1029-30.

6. Michael UA, Kenneth CO, Anthony AA. Spectrophotometric and thermodynamic studies of the charge-transfer interaction between diethylcarbamazine citrate and chloranilic acid. Chem Pharm Bull 1999;47:463-6.

7. Lee $\mathrm{AR}, \mathrm{Hu} \mathrm{TM}$. Determination of guaiphenesin in antitussive pharmaceutical preparations containing dextromethorphan by first-and second-derivative UV spectroscopy. J Pharm Biomed Anal 1994;12:747-52

8. Khalode KD, Waikar SB, Pasmane SP. A validated UV spectrophotometric method for the simultaneous estimation of Dextromethorphan hydrobromide and chlorpheniramine maleate. Int I Pharm Technol 2012;4:4690-9.

9. Joshi RS, Pawar NS, Sawant RL. Validated spectrophotometric methods for simultaneous estimation of acetaminophen chlorpheniramine maleate and caffeine in pue and tablate dosage form. Latt Am J Pharm 2010;29:1226-30.
10. Mahesh RJ, Jeyaprakash MR, Madhuri K, Meyyanathan SN Elango K. A sensitive RP-HPLC method for simultaneous estimation of diethylcarbamazine and levocetirizine in tablet formulation. Indian J Pharm Sci 2011;73:320-3.

11. Hamide C, Tuncel O. Simultaneous high-performance liquid chromatographic determination of paracetamol, phenylephrine $\mathrm{HCl}$, and chlorpheniramine maleate in pharmaceutical dosage forms. J Chromatogr Sci 2002;40:97-100.

12. Suzen S, Akay C. Cevheroglu S. Formaco 1999;54:705-9.

13. Kulikov AU, Aleksey GV. LC determination of lercanidipine and its impurities using DryLab software and experimental design procedures. J Chromatogr 2008;67:5-6.

14. Anand P, Varun R, Anagha D. Simultaneous analysis of intestinal permeability markers, caffeine, paracetamol and sulfasalazine by Reverse phase liquid chromatography: a tool for standardization of rat everted gut sac model. Asian J Pharm Clin Res 2010;3:204-7.

15. Suraj S, Prasanna KP, Sagar KM, Sabuj S. HPLC method development for simultaneous estimation of hydrochlorothiazide and perindopril in tablet dosage form. Asian J Pharm Clin Res 2012;5:136-8

16. Code Q2A-text on validation of analytical procedure step-3 Consensus Guideline; 1994.

17. ICH Harmonised Tripartite Guideline; 2015.

18. Code Q2B-Validation of analytical procedure methodology step-4 consensus guideline, ICH Harmonised Tripartite Guideline; 1994.

19. Prakash K, Sireesha KR. Liquid chromatographic method for simultaneous determination of lomefloxacin hydrochloride and dexamethasone sodium phosphate in eye drops. Asian J Pharm Clin Res 2012;5:79-82. 